\title{
Prediction of Adverse Perinatal Outcomes and Preeclampsia in Pregnant Women with Chronic Arterial Hypertension
}

\author{
Victor E. Radzinsky ${ }^{1}, \mathrm{PhD}, \mathrm{ScD}$; Bakhtykei M. Gasanova ${ }^{1}, \mathrm{PhD}$; Miroslava L. Polina, $\mathrm{PhD}^{2}$; \\ Natalya I. Douglas, PhD, ScD ${ }^{3}$; Praskovya N. Zakharova ${ }^{3}$; Tatyana V. Dedy, $\mathrm{PhD}^{4}$ \\ ${ }^{1}$ Peoples' Friendship University of Russia (RUDN University), Moscow, Russia \\ ${ }^{2}$ Women's Health Medical Center, Moscow, Russia \\ ${ }^{3}$ M. K. Ammosov North-Eastern Federal University, Yakutsk, Yakutia \\ ${ }^{4}$ Federal Medical-Biological Agency, Moscow, Russia
}

\begin{abstract}
The objective of this study was to determine predictors and develop a prognostic model for preeclampsia (PE) and adverse perinatal outcomes in pregnant women with chronic arterial hypertension $(\mathrm{CAH})$.

Methods and Results: The study cohort included pregnant women $(\mathrm{n}=376)$ with hypertensive disorders: Group 1 -pregnant women with $\mathrm{CAH}(\mathrm{n}=134)$, Group 2 - with PE on the background of CAH $(\mathrm{n}=242)$. Healthy pregnant women made up the control group $(\mathrm{n}=34)$. The diagnosis of pregnant women with $\mathrm{CAH}$ was made on the basis of existing national and foreign recommendations that an increase in SBP $\geq 140 \mathrm{mmHg}$ and/or DBP $\geq 90 \mathrm{mmHg}$ indicates CAH. All patients underwent the following examinations: a survey on a special questionnaire; an anthropometric examination; physical examination; an assessment of the content of uric acid (UA) in the blood serum and microalbuminuria (MAU) in the urine at 6-8 and 16-17 weeks of pregnancy; 12-lead ECG, echocardiography, 24-hour ambulatory blood pressure monitoring, sonography of the uterus, fetus, and placenta at 6-8 and 1618 weeks. It was found that an inappropriate left ventricular mass (LVM) in pregnant women with CAH, a certain "phenotype" of 24-hour ABPM and indicators of metabolic disorders demonstrate the systemic nature of organ damage and appear to be a predictor of adverse perinatal outcomes and the development of PE. The revealed changes in the LV structure, which are more significant in $\mathrm{PE}$ on the background of $\mathrm{CAH}$, suggest the association of concentric left ventricular hypertrophy and disorders of uteroplacental blood flow. Detecting abnormal blood flow from early pregnancy will reduce not only perinatal morbidity and premature birth, but also the probability of organ (LV myocardium, kidney) damage in women with CAH. To predict the risks of adverse perinatal outcomes in pregnant women with $\mathrm{CAH}$ and $\mathrm{PE}$, a number of factors were identified that have a statistically significant relationship with the studied complications. The developed model makes it possible to predict the probability of PE and unfavorable perinatal outcomes in pregnant women suffering from CAH with high efficiency (91.1\%).(International Journal of Biomedicine. 2021;11(4):422-427.)
\end{abstract}

Key Words: chronic arterial hypertension $\bullet$ preeclampsia $\bullet$ left ventricular mass $\bullet$ microalbuminuria $\bullet$ uric acid

For citation: Radzinsky VE, Gasanova BM, Polina ML, Douglas NI, Zakharova PN, Dedy TV. Prediction of Adverse Perinatal Outcomes and Preeclampsia in Pregnant Women with Gestational Hypertension. International Journal of Biomedicine. 2021;11(4):422-427. doi:10.21103/Article11(4)_OA5

\section{Abbreviations}

ABPM, ambulatory blood pressure monitoring; AUC, area under the ROC curve; BMI, body mass index; BP, blood pressure; CAH, chronic arterial hypertension; DBP, diastolic BP; FGR, fetal growth retardation; HU, hyperuricemia; IVST, interventricular septal thickness; LVPWT, left ventricular posterior wall thickness; LVM, left ventricular mass; LVMI, left ventricular mass index; LVH, left ventricular hypertrophy; LVDD, left ventricular diastolic dysfunction; MAU, microalbuminuria; MBP, mean blood pressure; PE, preeclampsia; PI, pulsation index; RWT, relative wall thickness; SBP, systolic BP; TDI, tissue Doppler imaging; UA, uric acid; PP, pulse pressure; UAr, uterine arteries; UCA, umbilical cord artery. 


\section{Introduction}

Chronic arterial hypertension (CAH), defined by clinical practice guidelines as SBP $(\geq 140 \mathrm{mmHg})$ and or DBP $((\geq 90$ $\mathrm{mmHg}$ ) before pregnancy or up to 20 weeks, complicates up to $5 \%$ of pregnancies. ${ }^{(1,2)}$ Modern advances in the study of hypertensive disorders in pregnant women indicate the need to expand the possibilities of preclinical PE prediction on the background of $\mathrm{CAH} .{ }^{(3,4)} \mathrm{CAH}$ is regarded as an independent clinical risk factor for PE. ${ }^{(5)}$ The probability of developing $\mathrm{PE}$ on the background of $\mathrm{CAH}$ is $20 \%-30 \%,{ }^{(2-4)}$ with severe hypertension (>170/110 $\mathrm{mmHg})-46 \%{ }^{(6)}$

ABPM is considered to be a better predictor of PE and FGR than conventional office monitoring, but it is not sensitive or specific enough for routine screening.(7) In pregnant women with $\mathrm{CAH}$, an unfavorable prognostic value is reported if there is no physiological decrease in $\mathrm{BP}$ at night or an increase in average nighttime BP. A chronic increase in BP without damage to target organs with stable indicators is associated with a smaller negative effect on the condition of the pregnant woman and the fetus than with PE. ${ }^{(8)}$ Magee et al. ${ }^{(9)}$ showed that "less strict" control of DBP does not lead to worsening of perinatal outcomes, compared to "strict" control, but increases the probability of severe hypertension.

Numerous studies indicate hypertension as a risk factor for pregnancy complications; ${ }^{(10)}$ however, the prognostic value of the structure and function of the left ventricular (LV) myocardium in pregnant women with $\mathrm{CAH}$ for the purpose of individualizing treatment appears to be poorly studied. The data on LVDD in pregnant women with CAH, which is effectively diagnosed by TDI, are widely presented. ${ }^{(11)}$

During pregnancy, MAU is considered as a preclinical marker of kidney damage in CAH; after 20 weeks, it proves to be a predictor of early PE in the presence of $\mathrm{CAH}^{\left({ }^{(12)}\right.}$ High sensitivity and low positive significance of MAU in predicting PE ( $88.9 \%$ and $22.2 \%$, respectively) were shown by Wang et al. ${ }^{(13)}$ Proteinuria threshold values for predicting adverse perinatal outcomes range from $300 \mathrm{mg}$ /day to 500 $\mathrm{mg} /$ day. ${ }^{(14)}$

An increase in UA levels is associated with the development of $\mathrm{PE}^{(15)}$ a stronger connection is found in gestational hypertension. ${ }^{(16)}$ Hyperuricemia (HU) is considered as a marker of inflammation of the trophoblast and placenta, development of fetal growth retardation (FGR), ${ }^{(17)}$ and premature birth in pregnant women with PE. ${ }^{(18)}$ It is reported that $\mathrm{HU}$ is associated with low gestational age and low weight of newborns, regardless of the presence or absence of proteinuria in pregnant women with $\mathrm{CAH} .{ }^{(19)}$

The objective of this study was to determine predictors and develop a prognostic model for PE and adverse perinatal outcomes in pregnant women with $\mathrm{CAH}$.

\section{Materials and Methods}

The study cohort included pregnant women $(n=376)$ with hypertensive disorders: Group 1 - pregnant women with CAH ( $\mathrm{n}=134)$, Group 2 - with PE on the background of $\mathrm{CAH}(\mathrm{n}=242)$. Healthy pregnant women made up the control group ( $\mathrm{n}=34)$. Written informed consent was obtained from all participants.

Inclusion criteria: single-child progressing pregnancy, the presence of $\mathrm{CAH}$ confirmed before pregnancy, the woman's informed consent for the use of biological material for scientific purposes.

The diagnosis of pregnant women with $\mathrm{CAH}$ was made on the basis of existing national and foreign recommendations that an increase in $\mathrm{SBP} \geq 140 \mathrm{mmHg}$ and/or $\mathrm{DBP} \geq 90 \mathrm{mmHg}$ indicates $\mathrm{CAH}$. The program of a patient's examination included a survey on a special questionnaire and an anthropometric examination using a standard method with the calculation of the BMI $\left(\mathrm{kg} / \mathrm{m}^{2}\right)$. In all women, we assessed the content of UA in the blood serum and MAU in the urine at 6-8 and 16-17 weeks of pregnancy.

Office BP was measured using a mercury sphygmomanometer, according to Korotkov's method. BP was measured 3 times, and the means of these measurements were used in the analyses. The 24-hour ABPM was performed at 1011, 21-22 and 32-33 weeks of pregnancy. The device was set to obtain $\mathrm{BP}$ readings at $15 \mathrm{~min}$ intervals during the day (7am$11 \mathrm{pm})$ and at $30 \mathrm{~min}$ intervals during the night (11pm-7am).

The following BP indicators were taken into account: systolic (SBP), diastolic (DBP), pulse, mean arterial pressure (MAP). The degree of nighttime BP reduction, or daily index, was defined as the ratio of the difference between daytime and nighttime BP to daytime BP (in \%). Nocturnal dipping was defined as a reduction in average SBP and DBP at night greater than $10 \%$ compared with average daytime values

Echocardiography was carried out according to the recommendations of the American Society of Echocardiography ${ }^{(20)}$ in $\mathrm{M}$ - and B-modes. LVM was calculated using the formula R. Devereux. ${ }^{(2)}$ The appropriate LVMM (in relation to height, SBP, gender, shock load) was determined ${ }^{(22)}$ : predicted $\mathrm{LVM}=55.37+6.64 \times$ height $\left(\mathrm{m}^{2.7}\right)+0.64 \times \mathrm{SW}$ $(\mathrm{g}-\mathrm{m} / \mathrm{beat})-18.07 \times$ gender, where SW (stroke work) in grammeters/beat [g-m/beat]) was computed as follows: cuff SBP $\times$ stroke volume $\times 0.0144$; female gender coefficient $=2$.

Observed LVM (oLVM) was divided by predicted LVM $(\mathrm{pLVM})$ and was expressed as a percentage (oLVM/pLVM). Inappropriate LVM was defined as an excess of $>28 \%$ from the predicted value (ie, oLVM/pLVM $>128 \%$ ).

RWT was calculated as IVST+LVPWT)/LV EDD. Increased RWT was defined as $\geq 0.45$. $^{(23)}$

LVMI was determined by dividing the LVMs by the body surface area in $\mathrm{m}^{2}$. A cut-off of $110 \mathrm{~g} / \mathrm{m}^{2}$ was used to define an increased LVMI. ${ }^{(24)}$

Four types of different LV geometry patterns were defined based on LVMI and RWT, as recommended by the American Society of Echocardiography ${ }^{(25)}$ :

-normal geometry (normal LV mass index and normal RWT),

-concentric remodelling (normal LV mass index but increased RWT),

-concentric hypertrophy (increased LV mass index and increased RWT),

-eccentric hypertrophy (increased LV mass index but normal RWT). 

imaging.

LV diastolic function was analyzed by tissue Doppler

Sonography of the uterus, fetus, and placenta was performed in real time according to the generally accepted method. Blood flow Dopplerometry at 6-8 and 16-18 weeks included the measurement of indices in the UA, after 24 weeks - in the UA, UCA and middle cerebral arteries of the fetus. The pulsation index (PI), resistance index (RI), and systolicdiastolic ratio (SDR) were assessed.

Statistical analysis was performed using statistical software package SPSS version 19.0 (Armonk, NY: IBM Corp.). The normality of distribution of continuous variables was tested by the Shapiro-Wilk test. Baseline characteristics were summarized as frequencies and percentages for categorical variables and as mean (M) and standard error of the mean (SEM) for continuous variables. Student's unpaired t-test was used to compare average values for data with normal distribution. Group comparisons with respect to categorical variables are performed using chi-square tests with Yates correction or, alternatively, Fisher's exact test when expected cell counts were less than 5. A probability value of $P \leq 0.05$ was considered statistically significant.

\section{Results and Discussion}

The average age of women in Group 1 was slightly higher than in Group 2 (Table 1). Excess body weight (BMI $\geq 25 \mathrm{~kg} / \mathrm{m}^{2}$ ) was detected in both trimesters to a greater extent in pregnant women in Group 2.

The study of the physiological functions of newborns revealed lower 1-minute and 5-minute Apgar scores in newborns from mothers of Group 2 and low birth weight, compared to the control group.

In general, $36.4 \%$ of newborns from mothers of Groups 1 and 2 had hypotrophy versus $8.8 \%$ of newborns from mothers of the control group $(P=0.007)$. Cerebral ischemia was detected in $41.7 \%$ of newborns from mothers of Groups 1 and 2 versus $8.8 \%$ of newborns from mothers of the control group $(P=0.003)$. Morphofunctional dismaturity was detected in $41.7 \%$ of newborns from mothers of Groups 1 and 2 and only in $2.9 \%$ newborns from mothers of the control group $(P<0.05)$.

To predict the risks of adverse perinatal outcomes in pregnant women with $\mathrm{CAH}$ and $\mathrm{PE}$, a number of factors were identified that have a statistically significant relationship with the studied complications (Table 2).

The identification of the presented risk factors made it possible to build a predictive model of the probability of the phenomena under study in each individual case.

The calculation was carried out according to the formula: $\mathrm{P}=1 /\left(1+\mathrm{e}^{\wedge}(-\mathrm{z})\right), \mathrm{z}=\mathrm{a}_{0}+\mathrm{a}_{1} \mathrm{x}_{1}+\mathrm{a}_{2} \mathrm{x}_{2}+\mathrm{a}_{3} \mathrm{x}_{3}+\ldots$ $+a_{n} x_{n}$, where $p$ is the probability of the outcome, $x_{1} \ldots x_{n}$ are the values of the predictors measured in a nominal, ordinal or quantitative scale, $a_{1} \ldots a_{n}$ - regression coefficients.

The ROC (Receiver Operating Characteristic) analysis confirmed the high diagnostic value of the obtained model (Figure 1). The effectiveness of the prognostic model for identifying the contingent with the risk of developing $\mathrm{PE}$ and unfavorable perinatal outcomes was confirmed
Table 1.

Characteristics of pregnant women and newborns in groups with hypertensive disorders

\begin{tabular}{|l|c|c|c|}
\hline \multicolumn{1}{|c|}{ Variable } & Group 1 & Group 2 & $P$-value \\
\hline Age, yrs & $34.6 \pm 3.7$ & $28.4 \pm 2.6$ & 0.171 \\
\hline $\begin{array}{l}\text { BMI in the second trimester, } \\
\mathrm{kg} / \mathrm{m}^{2}\end{array}$ & $25.8 \pm 2.9$ & $26.5 \pm 3.8$ & 0.884 \\
\hline $\begin{array}{l}\mathrm{BMI} \text { in the third trimester, } \\
\mathrm{kg} / \mathrm{m}^{2}\end{array}$ & $26.7 \pm 3.2$ & $28.2 \pm 1.7$ & 0.679 \\
\hline $\begin{array}{l}\text { BMI }>25 \mathrm{~kg} / \mathrm{m}^{2} \text { in the second } \\
\text { trimester }\end{array}$ & $49(28.5 \%)$ & $91(44.6 \%)$ & 0.841 \\
\hline $\begin{array}{l}\text { BMI }>25 \mathrm{~kg} / \mathrm{m}^{2} \text { in the third } \\
\text { trimester }\end{array}$ & $59(34.3)$ & $109(53.4 \%)$ & 0.849 \\
\hline $1-\mathrm{minute}$ Apgar score & $7.4 \pm 0.6$ & $6.8 \pm 0.3$ & 0.372 \\
\hline 5-minute Apgar score & $8.2 \pm 0.4$ & $7.5 \pm 0.3$ & 0.162 \\
\hline Birth weight, g & $3152 \pm 320$ & $2950.0 \pm 360$ & 0.675 \\
\hline Hypotrophy of newborns & $59(34.3 \%)$ & $78(38.2 \%)$ & 0.023 \\
\hline $\begin{array}{l}\text { Morphofunctional } \\
\text { dismaturity of newborns }\end{array}$ & $39(22.7 \%)$ & $64(31.4 \%)$ & 0.580 \\
\hline $\begin{array}{l}\text { Cerebral ischemia of } \\
\text { newborns }\end{array}$ & $66(38.4 \%)$ & $92(45.1 \%)$ & 0.034 \\
\hline
\end{tabular}

Table 2.

Risk factors for adverse perinatal outcomes in the presence of $\mathrm{CAH}$ and the development of $P E$

\begin{tabular}{|l|c|c|c|c|}
\hline \multicolumn{1}{|c|}{ Factors } & $\begin{array}{c}\text { Regression } \\
\text { coefficient B }\end{array}$ & $\begin{array}{c}\text { Wald } \\
\text { Statistics } \\
\chi^{2}\end{array}$ & P-value & Exp B \\
\hline UA >370 mmol/1 & 2.0 & 13.9 & 0.000 & 7.8 \\
\hline MAU & 0.96 & 4,2 & 0,04 & 2.6 \\
\hline LVDD & 1.5 & 9.1 & 0,003 & 4.5 \\
\hline oLVM/pLVM $>128 \%$ & 1.9 & 14.4 & 0.000 & 6.5 \\
\hline $\begin{array}{l}\text { Daily DBP }>60 \text { mmHg in } \\
\text { the first half of pregnancy }\end{array}$ & 1.1 & 4.6 & 0.03 & 2.8 \\
\hline Concentric LVH & 1.2 & 4.4 & 0.035 & 3.4 \\
\hline $\begin{array}{l}\text { Lack of early } \\
\text { antihypertensive therapy }\end{array}$ & 1.8 & 9.6 & 0.002 & 6.4 \\
\hline $\begin{array}{l}\text { Lack of placental } \\
\text { insufficiency prevention }\end{array}$ & 1.6 & 9.5 & 0.002 & 4.9 \\
\hline $\begin{array}{l}\text { PI ( }>1.55) \text { in the uterine } \\
\text { artery at 6-8 weeks }\end{array}$ & 1.3 & 4.9 & 0.027 & 3.8 \\
\hline Night-pickers & 1.9 & 14.8 & 0,000 & 7.3 \\
\hline BMI > 25 kg/m ${ }^{2}$ & 1.5 & 9.0 & 0.003 & 4.4 \\
\hline $\begin{array}{l}\text { Daily DBP }>68 \text { mmHg in } \\
\text { the second half of pregnancy }\end{array}$ & 1.1 & 5.1 & 0.024 & 2.9 \\
\hline Daily index (DBP) $<10$ & -1.7 & 12.9 & 0.000 & 0.180 \\
\hline $\begin{array}{l}\text { PI ( }>1.35) \text { in UAr at 16-18 } \\
\text { weeks }\end{array}$ & 2.3 & 17.0 & 0.000 & 10.1 \\
\hline Constant & -8.2 & 44.7 & 0.000 & 0.000 \\
\hline
\end{tabular}

by AUC-0.92. The Nagelkerke index (0.75) indicates the possibility of explaining $75.0 \%$ of the variance of the variables. The high prognostic value of the model with a selection of 
predictors is proved by the following criteria: sensitivity $84.3 \%$, specificity $-93.8 \%$, diagnostic efficiency $-91.1 \%$, PPV (positive predictive value) - 96.5\%, and NPV (negative predictive value) $-82.0 \%$. The cut-off criterion (0.5) is a sign of high predictive efficiency of the model, which is realized when the indicator is more than 0.5 .
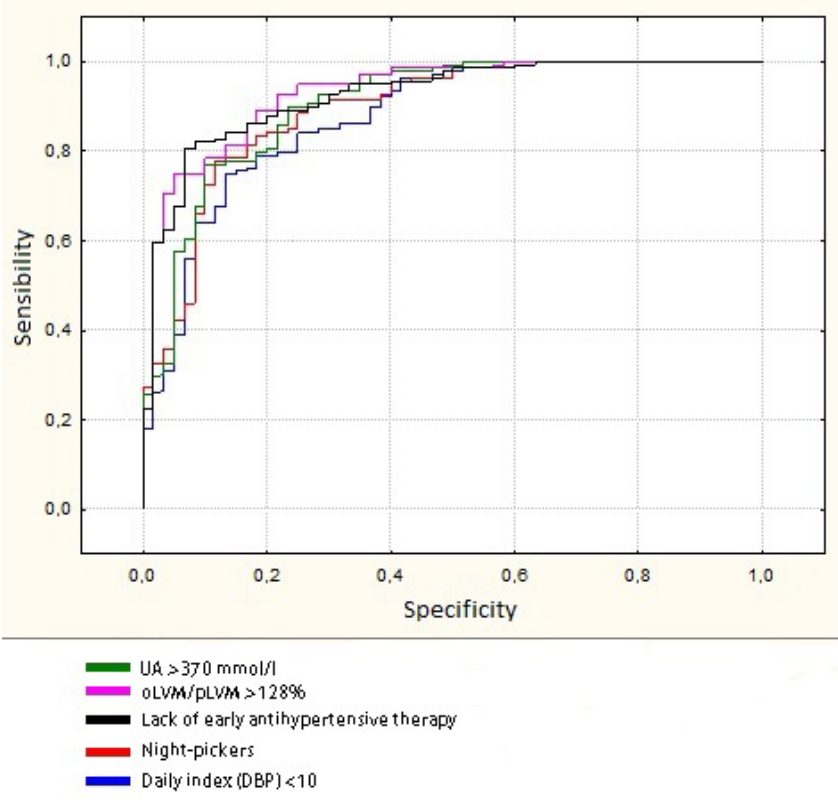

Fig. 1. The prognostic model for predicting the risk of developing PE and unfavorable perinatal outcomes

We have selected factors whose influence on the development of PE and adverse perinatal outcomes has been confirmed by many studies.

Evaluation of the uterine blood flow parameters as predictors of the consequences of limiting trophoblast invasion by the level of the decidual vascular segment allows us to identify violations of the cellular-molecular interactions between the mother and the fetus from the early stages of pregnancy. ${ }^{(26,27)}$

Our data confirm the informative value of the assessment of the PI in the UAr at 7-8 weeks $(>0.55)$ and at $16-18$ weeks $(>1.35)$ for detecting placental abnormalities and predicting $\mathrm{PE}$ in pregnant women with hypertensive disorders from early pregnancy. ${ }^{(28)}$ The diagnostic significance of measuring PI in UAr in each trimester of pregnancy (11-13.6 weeks, 2022.6 and 32-33.6 weeks) has been shown earlier, along with other factors (age of the pregnant woman, presence of $\mathrm{CAH}$, $\mathrm{PE}$ in the anamnesis). ${ }^{(29)}$ The expert assessment recognized the greatest effectiveness of the prognostic model of the third trimester (sensitivity $-79 \%$, specificity $-82 \%$ ).

The role of excess body weight as a factor predisposing to the development of $\mathrm{CAH}$ and $\mathrm{PE}$ has also been noted earlier.

The obvious advantages of ABPM in predicting the risks of PE are determined by the detection of night hypertension, ${ }^{(7)}$ belonging to night-pickers on the background of an average daily DBP $>60 \mathrm{mmHg}$ in the first half of pregnancy and $>68 \mathrm{mmHg}$ in the second half - as predictors of unfavorable perinatal outcomes. Similar data on an increase in the risk of PE with mean DBP of $\geq 75 \mathrm{mmHg}$ and $\mathrm{MBP}$ of $\geq 90 \mathrm{mmHg}$ at 13-20 weeks of pregnancy are given by other authors. ${ }^{(30)}$

LV geometry analysis turned out to be informative from the standpoint of clarifying the presence of organ damage the myocardium, kidneys and blood vessels, identified more often with prolonged hypertension. The process of cardiac remodeling, caused by a change in the thickness-radius ratio of the LV myocardium, with a greater LVM on the PE background, was realized in a change in the geometry of the concentric type, more often hypertrophy than remodeling.

The frequency of LV remodeling in pregnant women with $\mathrm{CAH}$ in the second trimester $(76.3 \%)$ and the third trimester $(85.4 \%)$ was higher than in foreign sources. ${ }^{(31)}$ This fact is probably due to the high frequency of delayed hypotensive therapy in the sample.

Conclusions about the adverse effect of abnormal LV geometry on the prognosis of the disease prevail in concentric hypertrophy. ${ }^{(32)} \mathrm{An}$ increase of concentric LVH (from 28.2\% to $38.6 \%$ ) by the third trimester indicates the expediency of identifying women who are threatened by the progression of $\mathrm{CAH}$.

The introduction of the variable oLVM/pLVM, which allows us to differentiate the risk group for severe hypertension and PE with an indicator " $>128 \%$," showing the presence of inappropriate LVM, regardless of the type of LVH, seems optimal when examining women with CAH.

The significance of LVDD, which is more often diagnosed in severe hypertension and the development of PE, has been confirmed by studies. In particular, Castleman et al. noted that in pregnancies complicated by $\mathrm{CAH}$ and $\mathrm{PE}$, differentiating features from normal pregnancy were LV wall thickness of $\geq 1.0 \mathrm{~cm}$, exaggerated reduction in $\mathrm{E} / \mathrm{A}$, and lateral e' of $<14 \mathrm{~cm} / \mathrm{s}^{(33)}$

Thus, monitoring of the LV myocardium makes it possible to stratify pregnant women in a timely manner by risk groups for the development of severe hypertension, the most significant in the absence of early hypotensive therapy. We believe that the assessment of LV function using echocardiography for women with long-term hypertension (more than two years) before planning pregnancy is reasonable.

Our data allow us to disagree with the opinion that routine testing for $\mathrm{HU}$ is inexpedient. ${ }^{(34)}$ The $\mathrm{UA}$ level $>370$ $\mu \mathrm{mol} / \mathrm{l}$ is defined as a predictor of PE, preceding changes in the structure and function of the LV myocardium in pregnant women with $\mathrm{CAH}$. The association of hyperuricemia with proteinuria and increased DBP, and with unfavorable perinatal outcomes, has been confirmed, in contrast to the findings of other authors. ${ }^{(35)}$

The presence of HU and MAU in pregnant women with $\mathrm{CAH}$ indicates a decrease in renal excretion on the background of parenchymal damage. ${ }^{(36,37)}$ The absence of proteinuria in $\mathrm{CAH}$ should be considered as an organ-protective factor.

Data on the possibility of predicting premature birth, early PE and FGR in pregnant women with impaired uterine blood flow in UA and abnormal biochemical tests explain the prognostic role of the absence of placental insufficiency prevention in $\mathrm{CAH}$. 


\section{Conclusion}

Thus, an inappropriate LVM in pregnant women with CAH, a certain "phenotype" of 24-hour ABPM and indicators of metabolic disorders demonstrate the systemic nature of organ damage and appear to be a predictor of adverse perinatal outcomes and the development of PE. The revealed changes in the LV structure, which are more significant in PE on the background of $\mathrm{CAH}$, suggest the association of concentric LVH and disorders of uteroplacental blood flow. Detecting abnormal blood flow from early pregnancy will reduce not only perinatal morbidity and premature birth, but also the probability of organ (LV myocardium, kidney) damage in women with $\mathrm{CAH}$. The developed model makes it possible to predict the probability of $\mathrm{PE}$ and unfavorable perinatal outcomes in pregnant women suffering from $\mathrm{CAH}$ with high efficiency $(91.1 \%)$.

\section{Competing Interests}

The authors declare that they have no competing interests.

\section{References}

1. Ananth CV, Duzyj CM, Yadava S, Schwebel M, Tita ATN, Joseph KS. Changes in the Prevalence of Chronic Hypertension in Pregnancy, United States, 1970 to 2010. Hypertension. 2019 Nov;74(5):1089-1095. doi: 10.1161/ HYPERTENSIONAHA.119.12968.

2. Scott G, Gillon TE, Pels A, von Dadelszen P, Magee LA. Guidelines-similarities and dissimilarities: a systematic review of international clinical practice guidelines for pregnancy hypertension. Am J Obstet Gynecol. 2020 Aug 20:S00029378(20)30846-2. doi: 10.1016/j.ajog.2020.08.018.

3. Nakanishi S, Aoki S, Nagashima A, Seki K. Incidence and pregnancy outcomes of superimposed preeclampsia with or without proteinuria among women with chronic hypertension. Pregnancy Hypertens. 2017 Jan;7:39-43. doi: 10.1016/j. preghy.2017.01.001.

4. Filipek A, Jurewicz E. Preeklampsja - choroba kobiet w ciąży [Preeclampsia - a disease of pregnant women]. Postepy Biochem. 2018 Dec 29;64(4):232-229. doi: 10.18388/ pb.2018_146. [Article in Polish].

5. Moussa HN, Leon MG, Marti A, Chediak A, Pedroza C, Blackwell SC, Sibai BM. Pregnancy Outcomes in Women with Preeclampsia Superimposed on Chronic Hypertension with and without Severe Features. Am J Perinatol. 2017 Mar;34(4):403-408. doi: 10.1055/s-0036-1592134.

6. Becker R, Vonk R. Doppler sonography of uterine arteries at 20-23 weeks: depth of notch gives information on probability of adverse pregnancy outcome and degree of fetal growth restriction in a low-risk population. Fetal Diagn Ther. 2010;27(2):78-86. doi: 10.1159/000274377.

7. Brown MA. Is there a role for ambulatory blood pressure monitoring in pregnancy? Clin Exp Pharmacol Physiol. 2014 Jan;41(1):16-21. doi: 10.1111/1440-1681.12106.

8. Tian TT, Li H, Chen SJ, Wang Q, Tian QW, Zhang BB, Zhu J, He GW, Lun LM, Xuan C. Serum Uric Acid as an Independent Risk Factor for the Presence and Severity of Early-Onset Coronary Artery Disease: A Case-Control
Study. Dis Markers. 2018 Oct 23;2018:1236837. doi: $10.1155 / 2018 / 1236837$.

9. Magee LA, von Dadelszen P, Rey E, Ross S, Asztalos E, Murphy KE, Menzies J, Sanchez J, Singer J, Gafni A, Gruslin A, Helewa M, Hutton E, Lee SK, Lee T, Logan AG, Ganzevoort W, Welch R, Thornton JG, Moutquin JM. Less-tight versus tight control of hypertension in pregnancy. N Engl J Med. 2015 Jan 29;372(5):407-17. doi: 10.1056/NEJMoa1404595.

10. Webster LM, Conti-Ramsden F, Seed PT, Webb AJ, Nelson-Piercy C, Chappell LC. Impact of Antihypertensive Treatment on Maternal and Perinatal Outcomes in Pregnancy Complicated by Chronic Hypertension: A Systematic Review and Meta-Analysis. J Am Heart Assoc. 2017 May 17;6(5):e005526. doi: 10.1161/JAHA.117.005526.

11. Zhou D, Huang Y, Fu M, Cai A, Tang S, Feng Y. Prognostic value of tissue Doppler E/e' ratio in hypertension patients with preserved left ventricular ejection fraction. Clin Exp Hypertens. 2018;40(6):554-559. doi: 10.1080/10641963.2017.1407332.

12. Moran P, Lindheimer MD, Davison JM. The renal response to preeclampsia. Semin Nephrol. 2004 Nov;24(6):588-95. doi: 10.1016/s0270-9295(04)00130-5.

13. Jayaballa M, Sood S, Alahakoon I, Padmanabhan $\mathrm{S}$, Cheung NW, Lee V. Microalbuminuria is a predictor of adverse pregnancy outcomes including preeclampsia. Pregnancy Hypertens. 2015 Oct;5(4):303-7. doi: 10.1016/j. preghy.2015.08.001.

14. Nipanal HV, Maurrya DK, Susmitha S, Ravindra PN. Analysis of Proteinuria Estimation Methods in Hypertensive Disorders of Pregnancy. J Obstet Gynaecol India. 2018 Dec;68(6):452-455. doi: 10.1007/s13224-017-1057-5.

15. Chen Q, Lau S, Tong M, Wei J, Shen F, Zhao J, Zhao M. Serum uric acid may not be involved in the development of preeclampsia. J Hum Hypertens. 2016 Feb;30(2):136-40. doi: 10.1038/jhh.2015.47.

16. Laughon SK, Catov J, Powers RW, Roberts JM, Gandley RE. First trimester uric acid and adverse pregnancy outcomes. Am J Hypertens. 2011 Apr;24(4):489-95. doi: 10.1038/ ajh.2010.262.

17. Bainbridge SA, Roberts JM, von Versen-Höynck F, Koch J, Edmunds L, Hubel CA. Uric acid attenuates trophoblast invasion and integration into endothelial cell monolayers. Am J Physiol Cell Physiol. 2009 Aug;297(2):C440-50. doi: 10.1152/ajpcell.00593.

18. Asgharnia M, Mirblouk F, Kazemi S, Pourmarzi D, Mahdipour Keivani M, Dalil Heirati SF. Maternal serum uric acid level and maternal and neonatal complications in preeclamptic women: A cross-sectional study. Int J Reprod Biomed. 2017 Sep;15(9):583-588.

19. Lin J, Hong XY, Tu RZ. The value of serum uric acid in predicting adverse pregnancy outcomes of women with hypertensive disorders of pregnancy. Ginekol Pol. 2018;89(7):375-380. doi: 10.5603/GP.a2018.0064.

20. Voigt JU, Pedrizzetti G, Lysyansky P, Marwick TH, Houle H, Baumann R, et al. Definitions for a common standard for 2D speckle tracking echocardiography: consensus document of the EACVI/ASE/Industry Task Force to standardize deformation imaging. Eur Heart $\mathrm{J}$ Cardiovasc Imaging. 2015;16(1):1-11. doi: 10.1093/ehjci/jeu184.

"Corresponding author: Miroslava L. Polina, PhD. Women's Health Medical Center, Moscow, Russia.E-mail: polina.ml@mail.ru 
21. Devereux RB, de Simone G, Ganau A, Roman MJ. Left ventricular hypertrophy and geometric remodeling in hypertension: stimuli, functional consequences and prognostic implications. J Hypertens Suppl. 1994;12(10):S117-27.

22. de Simone G, Verdecchia P, Pede S, Gorini M, Maggioni AP. Prognosis of inappropriate left ventricular mass in hypertension: the MAVI Study. Hypertension. 2002 Oct;40(4):470-6. doi: 10.1161/01.hyp.0000034740.99323.8a. 23. Koren MJ, Devereux RB, Casale PN, Savage DD, Laragh JH. Relation of left ventricular mass and geometry to morbidity and mortality in uncomplicated essential hypertension. Ann Intern Med. 1991 Mar 1;114(5):345-52. doi: 10.7326/00034819-114-5-345.

24. Devereux RB, Lutas EM, Casale PN, Kligfield P, Eisenberg RR, Hammond IW, Miller DH, Reis G, Alderman MH, Laragh JH. Standardization of M-mode echocardiographic left ventricular anatomic measurements. J Am Coll Cardiol. 1984 Dec;4(6):1222-30. doi: 10.1016/s0735-1097(84)80141-2.

25. Lang RM, Badano LP, Mor-Avi V, Afilalo J, Armstrong A, Ernande L, Flachskampf FA, Foster E, Goldstein SA, Kuznetsova T, Lancellotti P, Muraru D, Picard MH, Rietzschel ER, Rudski L, Spencer KT, Tsang W, Voigt JU. Recommendations for cardiac chamber quantification by echocardiography in adults: an update from the American Society of Echocardiography and the European Association of Cardiovascular Imaging. Eur Heart J Cardiovasc Imaging. 2015 Mar;16(3):233-70. doi: 10.1093/ehjci/jev014. Erratum in: Eur Heart J Cardiovasc Imaging. 2016 Apr;17(4):412.

26. Lamarca B. The role of immune activation in contributing to vascular dysfunction and the pathophysiology of hypertension during preeclampsia. Minerva Ginecol. 2010 Apr;62(2):105-20.

27. Poon LC, Karagiannis G, Leal A, Romero XC, Nicolaides KH. Hypertensive disorders in pregnancy: screening by uterine artery Doppler imaging and blood pressure at 11-13 weeks. Ultrasound Obstet Gynecol. 2009 Nov;34(5):497-502. doi: 10.1002/uog.7439.

28. Mönckeberg M, Arias V, Fuenzalida R, Álvarez S, Toro V, Calvo A, Kusanovic JP, Monteiro LJ, Schepeler M, Nien JK, Martinez J, Illanes SE. Diagnostic Performance of First Trimester Screening of Preeclampsia Based on Uterine Artery Pulsatility Index and Maternal Risk Factors in Routine Clinical Use. Diagnostics (Basel). 2020 Mar 26;10(4):182. doi: 10.3390/diagnostics10040182.

29. Mula R, Meler E, Albaiges G, Rodriguez I. Strategies for the prediction of late preeclampsia. J Matern Fetal Neonatal Med. 2019 Nov;32(22):3729-3733. doi: 10.1080/14767058.2 018.1471592.

30. Peyrin-Biroulet L, Williet N, Cacoub P. Guidelines on the diagnosis and treatment of iron deficiency across indications: a systematic review. Am J Clin Nutr. 2015 Dec;102(6):158594. doi: 10.3945/ajen.114.103366

31. Ambia AM, Morgan JL, Wells CE, Roberts SW, Sanghavi M, Nelson DB, Cunningham FG. Perinatal outcomes associated with abnormal cardiac remodeling in women with treated chronic hypertension. Am J Obstet Gynecol. 2018 May;218(5):519.e1-519.e7. doi: 10.1016/j. ajog.2018.02.015.

32. Kim MJ, Seo J, Cho KI, Yoon SJ, Choi JH, Shin MS. Echocardiographic Assessment of Structural and Hemodynamic Changes in Hypertension-Related Pregnancy. J Cardiovasc Ultrasound. 2016 Mar;24(1):28-34. doi: 10.4250/ jcu.2016.24.1.28.

33. Castleman JS, Ganapathy R, Taki F, Lip GY, Steeds RP, Kotecha D. Echocardiographic Structure and Function in Hypertensive Disorders of Pregnancy: A Systematic Review. Circ Cardiovasc Imaging. 2016 Sep;9(9):e004888. doi: 10.1161/CIRCIMAGING.116.004888.

34. Khaliq OP, Konoshita T, Moodley J, Naicker T. The Role of Uric Acid in Preeclampsia: Is Uric Acid a Causative Factor or a Sign of Preeclampsia? Curr Hypertens Rep. 2018 Jul 10;20(9):80. doi: 10.1007/s11906-018-0878-7.

35. Kumar N, Singh AK, Maini B. Impact of maternal serum uric acid on perinatal outcome in women with hypertensive disorders of pregnancy: A prospective study. Pregnancy Hypertens. 2017 Oct;10:220-225. doi: 10.1016/j. preghy.2017.10.002.

36. Chescheir NC. Serum Uric Acid Measurement in Women With Hypertensive Disorders of Pregnancy. Obstet Gynecol. 2019 Sep;134(3):636-638. doi: 10.1097/ AOG.0000000000003408.

37. Kang DH, Finch J, Nakagawa T, Karumanchi SA, Kanellis J, Granger J, Johnson RJ. Uric acid, endothelial dysfunction and pre-eclampsia: searching for a pathogenetic link. J Hypertens. 2004 Feb;22(2):229-35. doi: 10.1097/00004872200402000-00001. 